\title{
FAKTOR-FAKTOR YANG MEMPREDIKSI PURCHASE INTENTION SKIN CARE GARNIER DI INDONESIA
}

\author{
Clara Tanuwijaya dan Frangky Slamet \\ Program Studi Manajemen, Fakultas Ekonomi dan Bisnis, Universitas Tarumanagara Jakarta \\ Email: claratanuwijaya19@gmail.com
}

\begin{abstract}
Brand awareness is the consumer's ability to remember a brand, brand association is a positive / negative perception when remembering a brand, perceived quality is a customer evaluation of brand superiority, brand loyalty is a customer commitment to a brand, and purchase intention is an evaluation of consumers to decide to buy a product. This study aims to determine the predictions of brand awareness, brand association, perceived quality and brand loyalty to purchase intention with a conclusive quantitative method and a cross-section study. Data obtained by means of a survey made with "google form" sent via email and WhatsApp to 100 respondents who are people who have used the Garnier brand skin care for at least 3 years in Indonesia with a non-probability sampling method (purposive sampling). Then there are 4 hypotheses in this study which were analyzed using PLS-SEM with SmartPLS 3. The results of this study indicate that brand awareness, brand association, perceived quality and brand loyalty each predict positively the purchase intention of Garnier brand skin care users in Indonesia.
\end{abstract}

Keywords: Awareness, Association, Quality, Loyalty, Intention.

Abstrak: Brand awareness merupakan kemampuan konsumen untuk mengingat merek, brand association merupakan persepsi positif/negatif ketika mengingat merek, perceived quality merupakan evaluasi pelanggan pada keunggulan merek, brand loyalty komitmen pelanggan pada merek, dan purchase intention merupakan evaluasi konsumen untuk memutuskan beli produk. Penelitian ini bertujuan untuk mengetahui prediksi brand awareness, brand association, perceived quality dan brand loyalty terhadap purchase intention dengan metode kuantitatif berjenis konklusif dan cross-sectiona study. Data diperoleh dengan cara survei yang dibuat dengan "google form" yang dikirimkan melalui email dan whatsapp terhadap 100 responden yang merupakan orang yang menggunakan skin care merek Garnier minimal 3 tahun di Indonesia dengan metode non-probability sampling (purposive sampling). Kemudian terdapat 4 hipotesis pada penelitian ini yang dianalisis menggunakan PLS-SEM dengan SmartPLS 3. Hasil penelitian ini menunjukkan bahwa brand awareness, brand association, perceived quality dan brand loyalty masing-masing memprediksi positif purchase intention pengguna skin care merek Garnier di Indonesia.

Kata kunci: Awareness, Association, Quality, Loyalty, Intention.

\section{LATAR BELAKANG}

Industri kecantikan di Indonesia terus mencatat rekor penjualan yang meningkat dari tahun ke tahun serta menarik bagi investor asing maupun domestik. Berdasarkan Beauty Market Survey (2016) yang diperoleh dari data Nielsen dan Euromonitor, mencatatkan nilai penjualan tahunan industri kecantikan di Indonesia per 2016 tercatat mencapai Rp 36 triliun yakni naik $12 \%$ dari tahun sebelumnya (indonesia-investments.com). Kemudian tren industri kecantikan mengalami kenaikan pertumbuhan di mana data Nielsen (2018) mencatat bahwa 
pasar produk dari industri kecantikan bertumbuh sebesar 7\% dari tahun sebelumnya dengan nilai pasar (market value) sebesar Rp 40 triliun.

Salah satu produk dari industri kecantikan adalah skin care. Pasar produk perawatan kulit (skin care) di Indonesia menunjukkan tren pertumbuhan yang positif di mana bahwa produk skin care adalah kategori produk yang bertumbuh pesat di industri kecantikan. Menurut data Nielsen (2018) kategori produk skin care menjadi salah satu di antara enam kategori produk industri kecantikan yang mengalami pertumbuhan terbesar di mana pada tahun 2017 tercatat menghasilkan penjualan tahunan sebesar \$ 1,37 miliar, bertumbuh 9\% dari tahun 2016. Kemudian data tren penjualan tersebut juga didukung oleh data Statista, yang mencatat penjualan tahunan produk skin care di Indonesia pada tahun 2012 sebesar $\$ 1,02$ miliar. Sementara pada tahun 2017 , angka tersebut meningkat menjadi sebesar $\$ 1,37$, dan diprediksi mengalami kenaikan menjadi $\$ 1,88$ miliar di tahun 2022 (tirto.id).

Adapun terdapat beberapa brand produk skin care yang di jual di Indonesia yang sudah cukup terkenal sehingga dapat dengan mudah dikenali oleh masyarakat (EIBN Sector Reports, 2019). Salah satu brand dari skin care di Indonesia yang cukup terkenal adalah garnier. Data Top brand award (2019) mencatat bahwa pada kriteria brand sabun pembersih wajah, garnier menempati posisi ke tiga dengan top brand index sebesar 15,3\%, kemudian pada kriteria brand pembersih wajah, garnier menempati posisi ke dua dengan top brand index sebesar 21,1\%, dan di tahun 2020, kriteria brand krim pemutih, garnier menempati posisi ke dua dengan top brand index sebesar 14,7\% (topbrand-award.com).

Sebuah produk yang diciptakan memerlukan brand yang menjadikan konsumen mudah mengenali sebuah produk serta ciri khasnya yang membedakan dari produk-produk lainnya. Aaker (1991, h. 21) menyatakan sebuah brand dibentuk dan dikembangkan adalah agar menjadi simbol pembeda agar konsumen dapat mengidentifikasi barang/jasa dari penjual yang melindungi produsen dari pesaing dengan produk yang identik yang mana dapat menimbulkan purchase intention. Berdasarkan latar belakang tersebut maka judul untuk penelitian ini adalah: "Prediksi Brand Awareness, Brand Association, Perceived Quality dan Brand Loyalty terhadap Purchase Intention Produk Skin Care Garnier di Indonesia."

\section{KAJIAN TEORI}

\section{Gambaran Umum Teori}

Teori yang diacu pada penelitian ini adalah "Theory of Planned Behavior". Ajzen (1991, h, 171) menyatakan bahwa terdapat tiga anteseden yang dapat memprediksi purchase intention secara akurat, yakni: sikap/attitude toward behavior, norma subjektif/subjective norms, dan kontrol perilaku yang dirasakan/perceived behavioral control. Sikap mengacu pada penilaian individu mengenai konsekuensi dari melakukan perilaku, yang mendeskripsikan sejauh mana individu memiliki evaluasi/penilaian yang menguntungkan atau tidak dari perilaku yang dilakukan. Kemudian norma subjektif mengacu pada tekanan sosial yang dirasakan untuk melakukan atau tidak melakukan tindakan tertentu. Kontrol perilaku yang dirasakan mengacu pada kemudahan atau kesulitan yang dirasakan dalam melakukan perilaku yang mencerminkan pengalaman masa lalu untuk mengantisipasi hal yang tidak menguntungkan dan hambatan yang mungkin terjadi (Ajzen, 1991, h. 188)

\section{Definisi Konseptual Variabel}

Aaker (1991, h. 61) menyatakan brand awareness adalah "the likelihood that a potential buyer can recognise the brand as a member of a certain product category." Artinya Kemampuan pembeli untuk mengenali dan mengingat merek sebagai anggota dari kategori produk tertentu. Brand awareness menurut Hoang dkk. (2020, h. 436) adalah “customer's 
ability to identify a brand from different product categories and be aware of brand which can actively assist consumers in making purchasing decisions." Artinya kemampuan pelanggan dalam mengidentifikasi merek dari kategori produk yang berbeda dan mengetahui merek tertentu yang membantu konsumen untuk membuat keputusan pembelian. Maka brand awareness adalah kemampuan konsumen untuk mengidentifikasi, mengenali dan mengingat merek pada berbagai kondisi dan membedakan merek tersebut dengan merek lainnya yang dapat memunculkan keputusan pembelian.

Kotler dan Keller (2006, h. 188) menyatakan brand association adalah "positive or negative information pertaining a brand that is in consumers' mind, i.e. a part that is connected to the node of the brain memory which encompass all brand-related thoughts, feelings, perceptions, smells, colours, music, pictures, experiences, beliefs and attitudes." Artinya informasi positif/negatif merek di benak konsumen yang mencakup semua pikiran, perasaan, persepsi, bau, warna, music, gambar, pengalaman dan kepercayaan terkait merek. Brand association menurut Pike dkk. (2010, h. 437) adalah "Represents the actual image held by consumers, which might or might not be related to that intended in the brand identity." Citra aktual konsumen terhadap merek baik terkait atau tidak pada identitas merek itu sendiri. Maka brand association adalah semua aspek positif/negatif terkait ingatan konsumen pada merek dalam bentuk non fisik, seperti keunikan, inovasi, posisi pasar dan reputasi dari merek itu sendiri yang membantu konsumen membedakan produk pesaing.

Aaker (1991, h. 80) perceived quality adalah "customer's perception of the overall quality or superiority of a product or service with respect to its intended purpose, relative to alternatives." Artinya persepsi pelanggan atas keunggulan suatu produk/layanan sehubungan dengan tujuan yang dimaksud, relatif terhadap beberapa alternatif. Menurut Lee, Goh dan Nor (2019, h. 165) perceived quality adalah "the customers' general viewpoint towards the products or services of a brand which involves judgement on the added values of a product." Artinya sudut pandang konsumen pada produk/jasa suatu merek yang melibatkan evaluasi konsumen terhadap nilai tambah suatu produk. Maka perceived quality adalah persepsi atas evaluasi pelanggan pada keunggulan/superioritas dari produk/jasa suatu merek yang dibandingkan dengan produk/jasa sejenis lainnya yang membuat konsumen memilih merek tertentu daripada merek pesaing.

Aaker (1991, h. 39) menyatakan brand loyalty adalah "the attachment that a customer has to a brand which demonstrated by intent to purchase, and behavioral through word of mouth referrals and repeat purchase" Ketertarikan pelanggan pada merek yang ditunjukkan dengan niat membeli, merekomendasikan ke orang lain dan pembelian berulang. Hoang dkk. (2020, h. 438) menyatakan brand loyalty adalah "the attitudinal preference for a focal brand and the intention to buy the brand as a primary choice which willing to pay more for that brand." Artinya preferensi sikap untuk fokus dan niat untuk membeli merek sebagai pilihan utama dan bersedia membayar lebih untuk merek tertentu. Maka brand loyalty adalah komitmen konsumen yang dihasilkan atas niat/ketertarikan nya pada merek tertentu yang membuat konsumen menetapkan diri untuk terus membeli produk, merekomendasikan produk kepada orang lain dan perilaku pembelian berulang.

Yaseen dan Mazahir (2017, h. 86) menyatakan purchase intention adalah "the buyer's ability and judgement to evaluate the brand attributes." Artinya kemampuan dan penilaian pembeli untuk mengevaluasi merek. Menurut Mao dkk. (2020, h. 2) menyatakan purchase intention adalah "the customer's tendency or willingness to buy a certain product or service in the future." Artinya kecenderungan konsumen untuk membeli produk/layanan tertentu di masa depan maka purchase intention adalah kemampuan evaluasi konsumen dalam mengambil keputusan untuk membeli produk/jasa tertentu di masa depan pada persahaan yang sama dengan mempertimbangkan situasi dan kemungkinan. 


\section{Hubungan antar Variabel}

\section{Kaitan Brand Awareness dan Purchase Intention}

Brand awareness terkonsep dalam brand recognition dan brand recall, di mana brand recognition mengacu pada sejauh mana konsumen mengenali merek yang telah dilihat/didengar sebelumnya dan brand recall mengacu pada tingkat di mana ingatan konsumen terhadap merek merek yang dihasilkan ketika adanya petunjuk dari kategori produk (Keller, 1993) maka konsumen yang telah mengenal dan mengingat merek tertentu akan membuat keputusan untuk membeli produk/jasa dari sebuah merek (Lee, Goh dan Noor, 2019, h. 163). MacDonald dan Sharp (2000) menyatakan bahwa brand awareness mempengaruhi keputusan pembelian konsumen dalam tiga cara, yakni: memberikan peluang merek untuk menjadi pertimbangan konsumen, merek yang lebih dikenali oleh konsumen akan dibeli dan mengontrol pengambilan keputusan konsumen dari segi kualitas.

\section{Kaitan Brand Association dan Purchase Intention}

Brand association dapat dibentuk melalui sikap dari individu, atribut dan manfaat yang diperoleh dari merek (Keller, 1998). Brand association berfungsi untuk menimbulkan subjek dalam sebuah lintasan ingatan pada pikiran konsumen di mana hanya ada sebuah merek tertentu yang akan terlintas secara langsung dalam pikiran yang membantu konsumen untuk membuat keputusan pembelian terhadap merek tertentu (Lee, Goh dan Noor, 2019, h. 164). Persepsi dan emosi konsumen pada merek tertentu akan dijadikan pertimbangan untuk membeli suatu produk/jasa yang mana konsumen tidak hanya membeli produk secara langsung tanpa adanya pertimbangan atas citra produk itu sendiri, seperti kekuatan, kekayaan, keanggihan, identifikasi dan hubungan dengan merek lainnya (Evans dkk., 2006).

\section{Kaitan Perceived Quality dan Purchase Intention}

Perceived quality adalah hasil evaluasi konsumen atas nilai tambah yang terdapat pada produk secara spesifik yang mana jika perceived quality dirasa positif dapat memberi dampak pada pilihan konsumen dan mendorong purchase intention, menfasilitasi perbedaan, dan memberikan peluang perusahaan untuk menetapkan produk/jasa dengan harga yang lebih tinggi daripada produk/jasa sejenis dari perusahaan kompetitor (Aaker, 1991, h. 82). Lee, Goh dan Noor (2019, h. 161) menemukan kaitan positif antara perceived quality dan purchase intention.

\section{Kaitan Brand Loyalty dan Purchase Intention}

Brand loyalty mengacu pada kecenderungan konsumen untuk tetap setia pada sebuah merek tertentu meskipun terdapat perubahan harga dan fitur produk (Aaker, 1991, h. 44). Brand loyalty berkaitan dengan komitmen konsumen secara konstan untuk melakukan pembelian berulang dan berbicara hal-hal positif pada merek dari produk/jasa tertentu yang muncul karena pengalaman pembelian produk di masa lalu. Brand loyalty dapat dipahami berdasarkan tiga perspektif, yakni perilaku, sikap dan perspektif pilihan yang mana perilaku mengacu pada seberapa banyak konsumen membeli produk tertentu dan perspektif pilihan mengacu pada alasan melakukan pembelian secara spesifik (Lee, Goh dan Noor, 2019, h. 165-166). 


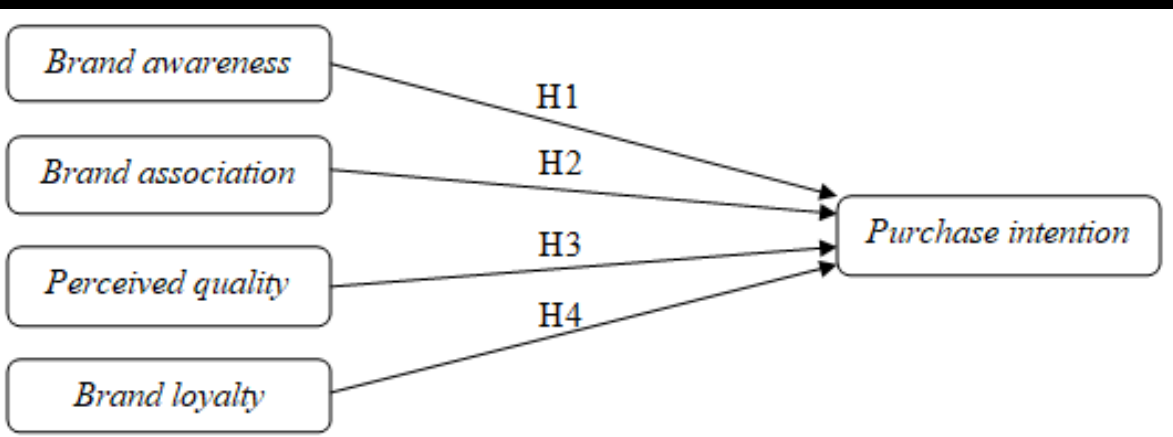

Gambar 1.

Kerangka pemikiran

Berdasarkan definisi variabel dan kerangka pemikiran yang dibahas, dapat ditetapkan hipotesis penelitian sebagai berikut:

H1 : Brand awareness merupakan prediktor positif purchase intention skin care Garnier.

$\mathrm{H} 2$ : Brand association merupakan prediktor positif purchase intention skin care Garnier.

H3 : Perceived quality merupakan prediktor positif purchase intention skin care Garnier.

H4 : Brand loyalty merupakan prediktor positif purchase intention skin care Garnier.

\section{METODOLOGI}

Sekaran dan Bougie (2013, h. 95) menyatakan desain penelitian adalah sebuah kerangka kerja untuk mengukur, mengumpulkan, dan menganalisis data yang diperoleh. Menurut Malhotra (2010, h. 103) menyatakan desain penelitian terbagi atas dua, yakni: penelitian konklusif dan eksploratif. Penelitian ini menggunakan desain penelitian konklusif yang bersifat kuantitatif karena data didapatkan berdasarkan sampel yang representatif. Malhotra (2015, h. 87) menyatakan penelitian konklusif merupakan jenis penelitian yang bertujuan untuk mendeskripsikan karakteristik/fungsi pasar di mana terbagi menjadi dua lagi, yakni penelitian deskriptif dan kausal. Pada penelitian deskriptif periode penelitian terbagi menjadi dua, yakni: cross sectional study dan longitudinal study. Penelitian ini termasuk cross sectional study karena data yang dikumpulkan tidak eksperimental dan penelitian dilakukan sekali selama periode penelitian (Sekaran dan Bougie, 2013). Populasi pada penelitian ini adalah semua orang di Indonesia yang menggunakan skin care Garnier. Sampel diambil menggunakan teknik non-probability sampling dengan pendekatan pusposive sampling yakni berdasarkan kriteria tertentu yaitu pengguna skin care merek garnier di Indonesia yang telah menggunakan garnier minimal tiga tahun dengan ukuran sampel 100 responden.

Dari 100 responden mayoritas adalah berjenis kelamin wanita sebanyak 74 orang (74\%), kemudian berdasarkan usia mayoritas responden berusia di antara 22-25 tahun sebanyak 64 orang (64\%). Selanjutnya berdasarkan pengeluaran per tahun untuk produk skin care Garnier, mayoritas responden mengeluarkan Rp 1 juta - Rp 2 juta sebulan untuk skin care Garnier sebanyak 42 orang (42\%). Lebih lanjut berdasarkan frekuensi pembelian skin care merek Garnier dalam setahun, mayoritas membeli 5-6 kali produk skin care Garnier yakni sebanyak 40 orang (40\%).

Pengumpulan data dilakukan dengan menggunakan kuesioner yang diberikan skor 1-5 berupa skala Likert. Data dianalisis menggunakan PLS-SEM dimana data diolah dengan program software SmartPLS 3. Pertama, pengolahan dilakukan pada outer model untuk menguji validitas dan reliabilitas. Analisis validitas dilihat dari nilai outer loadings $>0,5$ 
(Ghozali dan Latan, 2015, h. 74) dan nilai Average Variance Extracted > 0,5 (Hair dkk., 2011). Kemudian nilai cross loadings dengan kriteria "nilai outer loadings yang dihasilkan tiap indikator terhadap konstruk latennya harus lebih besar dibandingkan nilai outer loadings tiap indikator terhadap konstruk laten lainnya (Garson, 2016, h. 67). Analisis reliabilitas dilihat dari besarnya nilai pada cronbach alpha dan composite reliability menurut (Hair dkk., 2011) minimal diatas 0,6 suatu data yang digunakan dapat diklaim memiliki reliabilitas.

Kedua, pengolahan dilakukan pada inner model untuk menguji hipotesis yang telah dihasilkan. Sebelum pengujian hipotesis, pertama dilakukan pengujian konstruk penelitian dengan melihat nilai $\mathrm{R}$-square $\left(\mathrm{R}^{2}\right)$ nilai pada $\left(\mathrm{R}^{2}\right)$ sebesar $0,99-0,75$ maka variabel independen adalah prediktor yang bersifat substansial / kuat, jika nilai pada $\left(\mathrm{R}^{2}\right)$ sebesar 0,74 - 0,5 maka variabel independen adalah prediktor yang bersifat sedang / moderat, untuk nilai $\left(\mathrm{R}^{2}\right)$ sebesar 0,49-0,25 maka variabel independen adalah prediktor yang bersifat lemah (Hair dkk., 2011). Nilai q-square ditinjau dari Cohen (1988 dalam Garson, 2016, h. 118) menyatakan jika nilai yang dihasilkan $\mathrm{Q}^{2}$ antara 0,02-0,14 menunjukkan bahwa konstruk memiliki ukuran efek kecil (small effect size), kemudian jika nilai yang dihasilkan $\mathrm{Q}^{2}$ antara 0,15-0,34 menunjukkan bahwa konstruk memiliki ukuran efek sedang (medium effect size), selanjutnya jika nilai yang dihasilkan oleh $\mathrm{Q}^{2}>0,35$ menunjukkan bahwa konstruk memiliki ukuran efek besar (high effect size). Kemudian Nilai GoF (Goodness of Fit) dengan kriteria 0,1 "kelayakan model kecil", 0,25 "kelayakan model sedang", dan 0,36 "kelayakan model besar" (Wetzels, Shroder dan Oppen, 2009). Selanjutnya pengujian hipotesis, untuk melihat prediksi yang terjadi lihat (positif/ negatif) dari path coefficient (original sample) yang dihasilkan, dan menggunakan $t$-statistics $>1,645$ (hipotesis tidak ditolak) dan $p$-values $<0,05$ (hipotesis signifikan) (Hair dkk., 2011).

Variabel dan jumlah pernyataan yang digunakan dan yang akan diolah datanya dalam penelitian ini, tersaji dalam tabel 1 berikut ini:

Tabel 1. Konstruk penelitian

\begin{tabular}{|l|l|c|c|}
\hline No & \multicolumn{1}{|c|}{ Variabel } & Pernyataan & Sumber \\
\hline 1 & Brand Awareneess (X1) & 6 & \\
\hline 2 & Brand Association (X2) & 5 & \multirow{2}{*}{ Lee, Goh dan Noor (2019) } \\
\hline 3 & Perceived Quality (X3) & 4 & \\
\hline 4 & Brand Loyalty (X4) & 5 & \\
\hline 5 & Purchase Intention (Y) & 3 & \\
\hline
\end{tabular}

\section{Hasil Uji Statistik \\ Analisis Validitas}

Pada hasil validitas didapatkan semua angka pada setiap pernyataan $>0,5$ pada nilai outer loadings untuk setiap pernyataannya, dan didapatkan semua angka $>0,5$ pada nilai Average Variance Extracted / AVE maka semua pernyataan dan variabel yang digunakan sudah valid. Kemudian pada cross loadings, indikator BAW4 dan BL6 tidak lolos karena nilai yang dihasilkan antara indikator terhadap variabel latennya sendiri lebih kecil dibandingkan nilai yang dihasilkan antara indikator terhadap variabel laten lainnya, sehingga dua indikator dieliminasi

\section{Uji reliabilitas}

Pada hasil reliabilitas, maka berdasarkan hasil yang dikalkulasi oleh program SmartPLS 3, didapatkan semua angka pada nilai Cronbach's Alpha dan Composite Reliability untuk setiap pernyataannya adalah $>0,6$. Maka pernyataan yang digunakan dalam penelitian ini sudah reliabel berdasarkan kedua nilai reliabilitas, yakni Cronbach's Alpha dan Composite Reliability. 


\section{Pengujian konstruk penelitian}

Nilai R-square $\left(\mathrm{R}^{2}\right)$ yang dihasilkan sebesar 0,825 (bersifat kuat) pada variabel purchase intention. Memiliki arti, sebesar $82,5 \%$ variabel purchase intention dijelaskan oleh variabel brand awareness, brand association, perceived quality, dan brand loyalty. Dan sisanya sebesar $17,5 \%$ variabel purchase intention dijelaskan oleh variabel independen lain. Nilai q-square yang dihasilkan konstruk penelitian ini sebesar 0,592 yang artinya model memiliki relevansi prediktif yang tinggi sehingga ideal dijadikan konstruk penelitian dan nilai GoF yang dihasilkan adalah sebesar 0, 7405 yang artinya tingkat kesesuaian atau kelayakan pada model penelitian ini kuat.

Tabel 2

Hasil Pengujian Hipotesis

\begin{tabular}{|c|c|c|c|c|c|}
\hline Kode & Hipotesis & $\begin{array}{c}\text { Original } \\
\text { Sample }\end{array}$ & $\begin{array}{c}\text { T } \\
\text { statistics }\end{array}$ & P values & Kesimpulan \\
\hline H1 & $\begin{array}{c}\text { Brand Awareness } \rightarrow \\
\text { Purchase Intention }\end{array}$ & 0,205 & 1,695 & 0,045 & Diterima \\
\hline H2 & $\begin{array}{c}\text { Brand Association } \rightarrow \\
\text { Purchase Intention }\end{array}$ & 0,246 & 2,773 & 0,003 & Diterima \\
\hline H3 & $\begin{array}{c}\text { Perceived Quality } \rightarrow \\
\text { Purchase Intention }\end{array}$ & 0,242 & 2,109 & 0,018 & Diterima \\
\hline H4 & $\begin{array}{c}\text { Brand Loyalty } \rightarrow \text { Purchase } \\
\text { Intention }\end{array}$ & 0,269 & 2,635 & 0,004 & Diterima \\
\hline
\end{tabular}

\section{DISKUSI}

Dari hasil analisis data secara statistik yang telah dilakukan, pengujian pada model penelitian ini telah menghasilkan bahwa keempat hipotesis yang telah dirumuskan adalah diterima. Hipotesis pertama yang menyatakan "brand awareness merupakan prediktor positif purchase intention skin care garnier." Adalah diterima. Hasil penelitian ini sejalan dengan penelitian yang dilakukan oleh Lee, Goh dan Noor (2019, h. 161) yang menemukan adanya kaitan positif brand awareness terhadap purchase intention. Kemudian Hutter dkk. (2013, h. 342) menemukan brand awareness memiliki pengaruh positif terhadap purchase intention di mana purchase intention mengacu pada proses pengambilan keputusan yang dikembangkan dalam benak konsumen untuk membeli merek dari suatu produk/jasa. Lalu MacDonald dan Sharp (2000) menyatakan bahwa brand awareness mempengaruhi keputusan pembelian konsumen dalam tiga cara, yakni: memberikan peluang merek untuk menjadi pertimbangan konsumen, merek yang lebih dikenali oleh konsumen akan dibeli dan mengontrol pengambilan keputusan konsumen dari segi kualitas. Brand awareness mengacu pada kemampuan konsumen untuk mengidentifikasi, mengenali dan mengingat merek pada berbagai kondisi dan membedakan merek tersebut dengan merek lainnya yang dapat memunculkan keputusan pembelian ketika konsumen telah memutuskan pembelian pada suatu produk/jasa tertentu maka akan menimbulkan purchase intention dan ketika awareness konsumen terhadap suatu produk/jasa dari merek tertentu terus meningkat maka akan meningkatkan purchase intention untuk membeli produk/jasa tersebut.

Hipotesis kedua yang menyatakan "brand association merupakan prediktor positif purchase intention skin care garnier." Adalah diterima. Hasil penelitian ini sejalan dengan penelitian yang dilakukan Lee, Goh dan Noor $(2019$, h. 161) yang menemukan adanya kaitan positif brand association terhadap purchase intention. Kemudian Susilowati dan Sari (2020, h. 42) menyatakan brand association berkaitan dengan segala aspek yang menjadi perhatian 
konsumen dari suatu merek terkait karakteristik non fisik produk, keunikan, inovasi produk, posisi pasar dan reputasi yang berperan krusial dalam meningkatkan purchase intention. Lalu Hoang dkk. (2020, h. 444) juga menemukan brand association secara positif mempengaruhi purchase intention konsumen. brand association merupakan kekuatan dari manfaat yang ditawarkan dari merek yang menjadi alat pengumpul informasi untuk membantu konsumen menemukan dan membuat keputusan pembelian (Boisvert, 2011). Brand association dapat menjadi pengingat sebuah merek tertentu di dalam benak konsumen. Ketika konsumen membeli sebuah produk atau menggunakan layanan tertentu maka dibutuhkan kesesuaian dengan apa yang ada di pikiran konsumen tersebut (Gunawardane, 2015). Brand association mengacu pada semua aspek positif/negatif terkait ingatan konsumen pada merek dalam bentuk non fisik, seperti keunikan, inovasi, posisi pasar dan reputasi dari merek itu sendiri yang membantu konsumen membedakan produk pesaing hal ini jika terus ditingkatkan akan menimbulkan purchase intention yang terus meningkat untuk konsumen terus berniat membeli produk.

Hipotesis ketiga yang menyatakan "perceived quality merupakan prediktor positif purchase intention skin care garnier." Adalah diterima. Hasil penelitian ini sejalan dengan hasil penelitian Lee, Goh dan Noor (2019, h. 161) menemukan kaitan positif antara perceived quality dan purchase intention. Kemudian Susilowati dan Sari (2020, h. 43) menyatakan perceived quality merupakan penilaian konsumen atas superioritas dan kinerja dari produk/layanan yang dibandingkan dengan produk/layanan sejenis lainnya. Perceived quality adalah sebuah indikator utama yang menentukan nilai yang dirasakan konsumen pada sebuah merek. Ketika perceived quality dari sebuah merek dirasa baik maka menimbulkan loyalitas merek dan memicu purchase intention konsumen terhadap suatu merek tertentu (Foroudi dkk., 2018). Lalu Piriyasup dan Kim (2017, h. 29) menemukan bahwa terdapat kaitan yang kuat dan positif perceived quality terhadap purchase intention konsumen. perceived quality dapat mengukur potensi dan keepatan respon konsumen terhadap produk/jasa yang ditawarkan yang dihasilkan dari pengalaman konsumen ketika berinteraksi langsung dengan produk/jasa, dan menjelaskan kinerja sebenarnya dari produk/jasa (Brito dan Aguilar, 2007). Hoang dkk. (2020, h. 443) menemukan bahwa perceived quality berkaitan positif terhadap purchase intention. Perceived quality mengacu pada persepsi atas evaluasi pelanggan pada keunggulan/superioritas dari produk/jasa suatu merek yang dibandingkan dengan produk/jasa sejenis lainnya yang membuat konsumen memilih merek tertentu daripada merek pesaing. Ketika kualitas dari produk/jasa dari merek tertentu dianggap semakin baik maka akan meningkatkan purchase intention konsumen untuk membeli produk/jasa tersebut.

Hipotesis keempat yang menyatakan "Brand loyalty merupakan prediktor positif purchase intention skin care garnier." Adalah diterima. Hasil penelitian ini sejalan dengan hasil penelitian Lee, Goh dan Noor (2019, h. 165-166) menemukan kaitan positif antara perceived quality dan purchase intention di mana Brand loyalty dapat dipahami berdasarkan tiga perspektif, yakni perilaku, sikap dan perspektif pilihan yang mana perilaku mengacu pada seberapa banyak konsumen membeli produk tertentu dan perspektif pilihan mengacu pada alasan melakukan pembelian secara spesifik. Kemudian Yaseen dan Mazahir (2017, h. 93) juga menemukan bahwa terdapat pengaruh positif signifikan brand loyalty terhadap purchase intention konsumen karena brand loyalty berkaitan dengan niat konsumen untuk loyal terhadap suatu merek yang dapat merefleksikan purchase intention. Pembelian produk dengan merek yang sama secara permanen muncul ketika tingginya tingkat brand loyalty konsumen di mana konsumen yang loyal cenderung untuk membeli lebih banyak (Lee, Back dan Kim, 2009). Lalu Brand loyalty secara umum mengacu pada keterikatan yang dimiliki konsumen terhadap suatu merek dari produk tertentu di mana konsumen yang loyal terhadap suatu merek tidak akan melakukan evaluasi terlebih dahulu merek tersebut, tetapi mereka langsung membeli dengan yakin (Hoang dkk., 2020, h. 438). Kemudian brand loyalty ditunjukkan dengan komitmen dari konsumen potensial untuk membeli produk namun 
mereka tidak beralih pada merek dari produk yang sejenis (Troiville dkk., 2019). Brand loyalty mengacu pada komitmen konsumen yang dihasilkan atas niat/ketertarikan nya pada merek tertentu yang membuat konsumen menetapkan diri untuk terus membeli produk, merekomendasikan produk kepada orang lain dan perilaku pembelian berulang. Semakin konsumen tertarik untuk membeli produk/jasa dari merek tertentu secara berulang maka hal tersebut semakin akan meningkatkan purchase intention konsumen untuk membeli produk/jasa.

\section{PENUTUP}

Brand awareness, brand association, perceived quality dan brand loyalty masingmasing merupakan prediktor positif terhadap purchase intention skin care Garnier di Indonesia. Keterbatasan dalam penelitian ini adalah Faktor-faktor yang diteliti dan dijadikan variabel independen untuk memprediksi purchase intention hanya empat. Kemudian Penelitian ini meneliti pada konteks purchase intention skin care Garnier saja. Selanjutnya subjek penelitian yang digunakan pada penelitian ini hanya berdasarkan orang-orang yang dikenal saja yang sesuai kriteria penelitian. Maka disarankan Bagi pihak pemasar skin care Garnier disarankan untuk meningkatkan empat faktor yang dapat memprediksi secara positif purchase intention. kemudian bagi peneliti selanjutnya diharapkan menambah variabel independen baru yang dapat memprediksi purchase intention. Selanjutnya diharapkan untuk meneliti meneliti purchase intention pada konteks penelitian yang berbeda seperti meneliti purchase intention pada bidang jasa maupun destinasi sehingga hasil penelitian memliki cakupan yang luas dan dapat dikembangkan penggunaannya.

\section{DAFTAR PUSTAKA}

Aaker, D. A. (1991). Managing brand equity: Capitalizing on the value of a brand Name. New York: The Free Press, Macmilla.

Ajzen, I. (1991). The theory of planned behavior. Organizational Behavior and Human Decision Process, 50, 171-211.

EIBN Sector Reports. (2019). New sector reports cosmetics. EIBN. EU-Indonesia Business Network. Diakses pada (2020, Oktober 9). Dari: www.eibn.org.

Evans, M., Jamal, A. and Foxall, G. (2006). Consumer Behaviour, UK: John Wiley and Sons.

Garson, G. D. (2016). Partial least squares: regression \& structural equation models. North Carolina: Statistical Associates Publishing.

Ghozali, I dan Latan, H. (2014). Structural equation modeling, metode alternatif dengan

Partial Least Square (PLS). Edisi 4. Semarang: Badan Penerbit Universitas Diponegoro.

Hair Jr, J. F., Black, W. C., Babin, B. J., \& Anderson, R. E. (2011). Multivariate data analysis 7th Edition. New Jersey: Pearson Prentice Hall.

Hoang, P. V., Nguyen, G. T., Phung, H. T. T., Ho, V. T., \& Phan, N. T. (2020). The relationship between brand equity and intention to buy: the case of convenience stores. Independent Journal of Management \& Production, 11(2), 434-449.

Keller, K.L. (1993). Conceptalizing, measuring, and managing customer-based brand equity. Journal of Marketing, 57(1), 1-22.

Kotler, P. and Keller, K.L. (2006). Marketing management, 12th ed. New Delhi: PrenticeHall of India.

Lee, Jia En., Goh, Mei Ling., dan Noor, M.N.B.M. (2019). Understanding purchase intention of university students towards skin care products. PSU Research Review, 3(3), 161178. 
MacDonald, E.K. and Sharp, B.M. (2000). Brand awareness effects on consumer decision making for a common, repeat purchase product: a replication. Journal of Business Research, 48(1), 5-15.

Malhotra, N. K. (2010). Essentials of marketing research. England: Pearson Educated Limited.

Malhotra, N. K. (2015) Essentials of Marketing Research. Harlow: Pearson Education Limited.

Mao, Y., Lai, Y., Luo, Y., Liu, S., Du, Y., Zhou, J., ... \& Bonaiuto, M. (2020). Apple or huawei: understanding flow, brand image, brand identity, brand personality and purchase intention of smartphone. Sustainability, 12(8), 1-22.

Nielsen. (2018, Oktober 29). Consumers don't always take skin care claims at face value. Nielsen.com. diakses pada (2020, Oktober 23). Dari: https://www.nielsen.com/us/en/insights/article/2018/consumers-dont-always-takeskin-care-claims-at-face-value $1 /$.

Pike, S., Bianchi, C., Kerr, G., \& Patti, C. (2010). Consumer-based brand equity for australia as a long-haul tourism destination in an emerging market. International Marketing Review, 27(4), 434-449.

Sekaran, U., \& Bougie, R. (2013). Research Methods for Business. 6th ed. Italy: Printer Trento Srl.

Top brand award. (2019). Top brand pembersih wajah bukan sabun. Topbrand-award.com. diakses pada (2020, November 2) Dari: https://www.topbrandaward.com/en/2019/04/pembersih-wajah-bukan-sabun/.

Top brand award. (2019). Top brand sabun pembersih wajah. Topbrand-award.com. diakses pada (2020, November 1) Dari: https://www.topbrand-award.com/en/2019/04/sabunpembersih-wajah/.

Top brand award. (2020). Top brand krim pemutih. Topbrand-award.com. diakses pada (2020, November 2) Dari: https://www.topbrand-award.com/2020/04/top-brandindex-tracking-krim-pemutih/.

Wetzels, M., Odekerken-Schroder, G., \& Oppen, C. (2009). Using PLS Path modelling for assessing hierarchical construct models: guidelines and empirical illustration. Assessing Hierarchical Construct Models. 33(1), 177-195.

Yaseen, S., \& Mazahir, I. (2019). Impact of corporate credibility, brand awareness, brand image and brand loyalty on purchase intention in the telecommunication sector of Karachi. Global Management Journal for Academic \& Corporate Studies, 9(1), 8699. 